\title{
Recovery of urban development stages of town Rashkiv
}

\author{
Illia Lytvynchuk, Mykola Bevz \\ Department of Restoration of Architectural and Artistic Heritage, \\ Lviv Polytechnic National University; (032) 258-22-08
}

\section{Bogusław Szmygin \\ Department of Heritage Conservation, Lublin University of Technology; (+4881) 5384389}

\begin{abstract}
Summary: In this article, the authors considered the development of Rashkiv (Raszków in Polish and Raşcov in Rumunian), the fortified settlement which is situated on the Middle part of the Lower Dnister Region. An attempt of reconstruction of the most important stages of its town-planning biography of the $15^{\text {th }}-18^{\text {th }}$ centuries was made. The authors based their research on newly identified sources. The systematization of the historical chronology of the most important events which have influenced the formation of the defensive structures and the urban environment of Rashkiv has been carried out. In the course of the $15^{\text {th }}-18^{\text {th }}$ centuries, four major urban planning periods were identified: the Lithuanian - fort Karaul in the form of a defensive roundel type castle, further - Zamoyski's town fortress with a fortified downtown, then - the fortifying of the suburbs and, finally, - trade and handicraft town without any defense function. At each stage, an attempt was made to hypothetically localize separate elements of the city - fortifications, historical roads, street planning system, civil and sacral dominant elements. The authors all available source data - archival sources, historical and contemporary cartography, toponymics, field surveys, surveys, and iconographic materials for analysis.

Remains of the $1^{\text {st }}$ period represent today ruins of earth shafts under the fortress. This hillfort is monument of archeological heritage and it is protected by state. Ukrainian historian M. Hrushevskyi connects appearance of the fort here with necessity todefend the river crossing and the trading way.

From the $2^{\text {nd }}$ period we have today just two preserved bastions of the early of $17^{\text {th }}$ century and some relicts of urban planning system, for example, part of the historical market square.

The article also substantiates the value and necessity of preserving the historical plan of Rashkiv which was, in particular, developed under the influence of the development of defense strategies of its time.

$3^{\text {rd }}$ period was graphically hypothetically reconstructed in many ways. To a greater extent it is because we have not enough materials to create a definite model of the urban development of this period.

Research is based on historical topographic works of $17^{\text {th }}$ and $18^{\text {th }}$ centuries and onlysince the early $19^{\text {th }}$ century we have more detailed historical plans to make more far reaching hypotheses. Using historical photos of early $20^{\text {th }}$ century, authors succeeded in discovering historically determined rhythm of urban environment in Rashkiv. Unfortunately, it is disappearing now due the physical ruining of historical substance of old town and reconstruction according present-day inhabitants' ideas about country houses or summer cottages.

The present results are significant in elaborating historical and reference architectural plan of the settlement, registration of the newly discovered objects of cultural heritage as monuments of architecture and urban planning, archeology, history and nature. New master plan of Rashkiv urban development should be based on our complex architectural and urban planning research to preserve cultural legacy of Rashkiv and to use it for modern economical and tourist revival.
\end{abstract}

Keywords: town of Rashkiv (Raszków), Podilia, Dnister, urban structure, fortification, castle, settlement, urban development, $15^{\text {th }}-18^{\text {th }}$ centuries.

\section{State of the problem. Analysis of the results of previous studies}

The numerous mentioning of the town of Rashkiv (Raszków in Polish) in the famous trilogy of the Polish writer Henryk Sienkiewicz testifies to the extraordinary role of this fortified place in the historical events of the $17^{\text {th }}$ 
century. What were the architectural and urban structure and the system of fortifications of this former well-fortified town, which is now a village, the traces of ancient greatness of which can be read only by the eyes of a very experienced professional researcher.

As of today, comprehensive historical and architectural studies of Rashkiv have not been conducted. A significant problem is the lack of historical documentary records, some of which had been made public in the second half of the 19th century, and the originals were lost during the Second World War. The only meaningful work devoted to Rashkiv is the article by Volodymyr Antonovych from 1897 called "НБсколько данныхъ о землевладЬніи въ южной Украинь въ XV стольтіи" [Some data on land tenure in southern Ukraine in the $15^{\text {th }}$ century] [1], in which an essay describing the history of the town with the attempt to localize the Lithuanian castle Kalaur (Karavul) is provided. There is a mentioning of Kalahur also in the work of Molchanovskyi from 1885. [2]. The research of the history of Lithuanian Rashkiv-Karavul was also joined by M. Hrushevskyi during the preparation of a review of the aforementioned article by Antonovych [3]. Local history information about Rashkiv was published by Guldman, Sytsynskyi, Bilynskyi and Lipynskyi and Dr. Antoni (J. Rolle). "Słownik Geograficzny..." mistakenly dates Rashkiv back to $17^{\text {th }}$ century. [4]. No materials about the study of the historical and cultural heritage of Rashkiv by Ukrainian scholars during the interwar period were found. After the inclusion of the Ukrainian Transnistria to the Moldavian SSR, the historical heritage of Rashkiv was isolated from the Polish and Ukrainian contexts, and as a result it led to a number of inaccuracies in the interpretation of cultural heritage objects. So, the Soviet Moldavian archaeologists Chetraru and Hîncu considered the castle Karaul, already discovered by V. Antonovych in 1888, as fortification of the Russian army of 1711, which forced a crossing over Dnister to help the Moldovan Voivode [5] . The absurdity of this statement will be explained below. Castle Karaul was included to the neighboring Caterinovca village council and no longer appeared in the information about Rashkiv. In addition, the development of the historic-architectural key plan of Rashkiv in the 1970's by the state project institute "Moldgiprograzhdanselstroy" in Chișinău was conducted without taking the entire historical heritage into account. On their key plan, only dispersedly located objects of the Baroque architectural heritage of the 18th century are marked, and disharmonious objects of the Soviet period in the historic center are defined as "having architectural merit", historic valuable and ordinary buildings in most cases were offered for demolition. In accordance with this key plan, in 1975, a new general plan of the village [6] and a detailed plan of the central part were worked out. Plans developers - V. Ostrovsky, V. Postoyeva, T. Rodionova., O. Dubrovskaya - obviously neglected the historical heritage of the town. Fortunately, this general plan was not implemented, and with the collapse of the USSR and the establishment of the unrecognized Pridnestrovian Moldavian Republic's authorities in Rashkiv, all work on the research of the architectural environment of Rashkiv also were ceased.

The development of our hypotheses concerning the development of Rashkiv relies on the work of Ukrainian scholars S. Kravtsov [7], M. Bevz [8, 9], O. Rybchynskyi [10,11] and the formulated by them theoretical principles of identification of the historical and urban structure of cities and towns of the Western and Right-bank Ukraine. Taking into account the location of Rashkiv in a single cultural space with the mentioned territories and colonization movements from west to east and from north to south in the $15^{\text {th }}-18^{\text {th }}$ centuries in the territory of Ukraine, our research is based on the techniques developed in the above-mentioned papers.

Objective of the article: to analyze materials on the history of Rashkiv, to explore the town on site, to discover the remnants of the historical planning structure and fortifications; to reconstruct on this basis the processes of the urban genesis of the town in the $15^{\text {th }}-18^{\text {th }}$ centuries. 


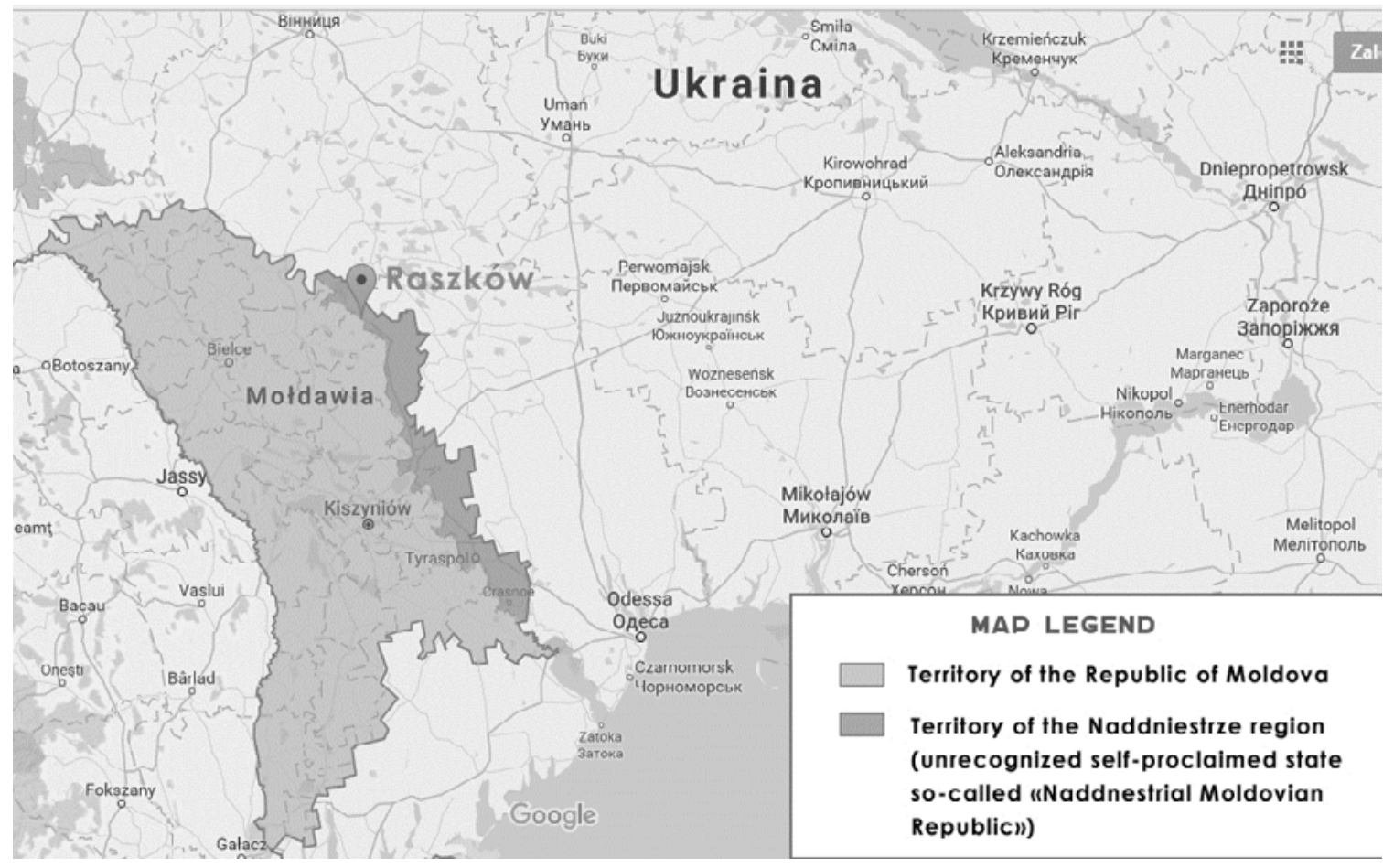

Fig. 1. Location plan of Rashkiv (Raszków, Raşcov).

Introduction. The historic town of Rashkiv de jure is located on the territory of the Transnistrian region of the Republic of Moldova (de facto it is controlled by the unrecognized Pridnestrovian Moldavian Republic) in the Camenca district on the picturesque left bank of the Dnister (Fig. 1). Before the second division of Poland it was its border outpost on the border with Turkish Moldova. It was founded in the 15th century by Grand Duke Vytautas, gained the city status during the possession of Jan Zamoyski at the end of the 16th century. His son, Tomasz, fortified the town according to the project by Andrea dell'Aqua in the early 17th century. At the end of the 18th century, Russian imperial authorities deprived Rashkiv of its urban status, and in Soviet times, Rashkiv became an ordinary village. All this lead to decay of the central historical part. Today, it becomes relevant to find out the biography of the town's architectural and urban environment and to identify its authentic elements.

\section{Presentation of research results}

Based on the study of all available published and archival sources, the authors have reconstructed the course of all historical events associated with the town. The beginnings of the settlement are connected with the time when the territory of Lower Part of the Dnister region was part of the Lithuanian-Ruthenian state. Based on data of I. Daniłowicz, it can be assumed that in the place of the current Rashkiv there was a fortified point in the interval between 1402 and 1411. [14]. Molchanovskyi disproves this date, and dates it back to 1432. [2]. The same dating is confirmed by Hrushevskyi [3] and by most contemporary researchers of the history of the Grand Duchy of Lithuania. Although until 1432, Karaul castle was referred to at least in the year 1411 in the chronicle of Długosz about the visit of King Władysław Jagiełło to the border fortresses [12]. Since among the Podilian towns in the document on the purchase of Podilia by Vytautas from Jogaila dated 1395 we do not find Karaul $[2,13]$, it is possible to establish the chronological limits of its origin and construction exactly between 1395 and 1411.

In 1442, a documentary confirmed transfer of Karaul and Rashkiv by the Polish King Władysław III to the nobleman Teodoryk Buczacki took place. Although M. Hrushevskyi considers the possession over Kalaur by Teodoryk Buczacki as nominal [3], it is difficult to agree with him, knowing the active construction and fortification activities of the members of the Buczacki family. 
Table 1. Analysis of the chronology of Rashkiv main historical events according to published and archival sources

\begin{tabular}{|c|c|c|c|}
\hline Year & Event & Ownership & $\begin{array}{c}\text { Type of } \\
\text { fortifications }\end{array}$ \\
\hline $1402 / 1411$ & $\begin{array}{c}1^{\text {st }} \text { mentioning of Kalaur (Karaul), founded } \\
\text { by the Grand Duke of Lithuania Vytautas } \\
{[14: 330-331 ; 15: 111-115 ; 16]}\end{array}$ & $\begin{array}{l}\text { State (Grand Duchy of } \\
\text { Lithuania) }\end{array}$ & Castra (castle) \\
\hline 1442 & $\begin{array}{l}\text { Transfer of Karavul and Rashkiv to Teodoryk } \\
\text { Buczacki by the Polish King Władysław III }\end{array}$ & $\begin{array}{l}\text { Private (Teodoryk } \\
\text { Buczacki Jazłowiecki) }\end{array}$ & $-/ /-$ \\
\hline 1545 & Development of Rashkiv & Private (Hrytsko Chechel) & Unknown \\
\hline $1590 s$ & Purchase by Jan Zamoyski & Private (Jan Zamoyski) & $\begin{array}{l}\text { Castle-residence }+ \\
\text { osada (settlement) }\end{array}$ \\
\hline 1600 & $\begin{array}{c}\text { Capture of Rashkiv and of the castle by } \\
\text { K. Ostrogski }\end{array}$ & $\begin{array}{l}\text { Private (prince Vasyl } \\
\text { Konstanty Ostrogski) }\end{array}$ & $-/ /-$ \\
\hline 1617 & $\begin{array}{l}\text { Voluntary destruction of Rashkiv and the } \\
\text { castle by Poles at the request of the Turks }\end{array}$ & $\begin{array}{c}\text { Private (prince } \\
\text { Aleksander Ostrogski) }\end{array}$ & Ruined \\
\hline 1625 & $\begin{array}{l}\text { Fortification of the city according to the } \\
\text { project of Andrea dell'Aqua by subordinate } \\
\text { of T. Zamoyski Jerzy Trzycki }\end{array}$ & $\begin{array}{l}\text { Private (Tomasz } \\
\text { Zamoyski) }\end{array}$ & $\begin{array}{l}\text { Wooden castle, } \\
\text { earthen bastion } \\
\text { town fortifications }\end{array}$ \\
\hline 1633 & $\begin{array}{c}\text { Destruction of fortifications by Abaza } \\
\text { Pasha's troops }\end{array}$ & $-/ /-$ & $-/ /-$ \\
\hline 1634 & $\begin{array}{l}\text { Restoration of fortifications, the request of } \\
\text { Sultan Murad IV to demolish the fortresses } \\
\text { of Rashkiv, Yampil and Mohyliv [17: } \\
\text { 150-151] }\end{array}$ & $-/ /-$ & $-/ /-$ \\
\hline 1646 & $\begin{array}{l}\text { Award for Jerzy Trzycki from Tomasz } \\
\text { Zamoyski for long-term work in the } \\
\text { development of Rashkiv [1] }\end{array}$ & $-/ /-$ & $-/ /-$ \\
\hline 1648 & Inclusion of Rashkiv to Bratslav regiment & $\begin{array}{l}\text { Private (St. Koniecpolski } \\
\text { (de jure)/Tymish } \\
\text { Khmelnytsky (de facto) }\end{array}$ & $-/ /-$ \\
\hline 1652 & $\begin{array}{l}\text { Marriage of Tymish Khmelnytsky with } \\
\text { Ruxandra Doamna }\end{array}$ & \multirow{4}{*}{$\begin{array}{l}\text { Private (St. Koniecpolski } \\
\text { (owner)/ Ruxandra } \\
\text { Doamna Khmelnytsky } \\
\text { (hypothecary ownership) }\end{array}$} & $-/ /-$ \\
\hline 1665 & $\begin{array}{c}\text { Capture of Rashkiv by Hetman Petro } \\
\text { Doroshenko }\end{array}$ & & $-/ /-$ \\
\hline 1671 & $\begin{array}{c}\text { Capture of Rashkiv by Great Crown Hetman } \\
\text { Jan Sobieski }\end{array}$ & & $-/ /-$ \\
\hline 1675 & $\begin{array}{c}\text { Capture of Rashkiv by Ibrahim Pasha } \\
\text { [18:136], mentioning about a fortified } \\
\text { monastery [19: } 106-107]\end{array}$ & & $-/ /-$ \\
\hline $1699-1703$ & $\begin{array}{l}\text { Rashkiv's return to Poland under the } \\
\text { conditions of the Treaty of Karlowitz }\end{array}$ & $\begin{array}{l}\text { Private (princes } \\
\text { Koniecpolski) }\end{array}$ & $-/ /-$ \\
\hline 1711 & $\begin{array}{l}\text { Purchase of Rashkiv by the family of } \\
\text { princes Lubomirski }\end{array}$ & $\begin{array}{l}\text { Private (princes } \\
\text { Lubomirski) }\end{array}$ & $-/ /-$ \\
\hline 1728 & $\begin{array}{l}\text { Restoration of city fortifications by } \\
\text { Lubombirski's constable Michal Roguzki }\end{array}$ & $\begin{array}{l}\text { Private (Jerzy } \\
\text { Lubomirski) }\end{array}$ & "walls" \\
\hline 1734 & $\begin{array}{c}\text { Haidamakas rebellion headed by Sava } \\
\text { Chalenko }\end{array}$ & $-/ /-$ & $-/ /-$ \\
\hline
\end{tabular}




\begin{tabular}{|c|c|c|}
\hline \multirow[t]{2}{*}{$1749-1786$} & $\begin{array}{c}\text { Construction of the Armenian-Catholic } \\
\text { Church at the cost of the priest } \\
\text { Krzysztofowicz }\end{array}$ & $\begin{array}{l}\text { Private (Stanisław } \\
\text { Lubomirski) }\end{array}$ \\
\hline & $\begin{array}{c}\text { The last attack of the Crimean Tatars on the } \\
\text { settlement along the Dnister, destruction } \\
\text { of Rashkiv }\end{array}$ & $-/ /-$ \\
\hline 1778 & $\begin{array}{c}\text { Construction of the Ukrainian Orthodox } \\
\text { church of the Holy Trinity on the initiative } \\
\text { of Kyiv's priest Palukhovych }\end{array}$ & $-/ /-$ \\
\hline $1780 \mathrm{~s}$ & $\begin{array}{l}\text { Construction of the new stone Greek } \\
\text { Catholic church of Our Lady's Mantle }\end{array}$ & $-/ /-$ \\
\hline 1792 & $\begin{array}{l}\text { Second partition of Poland, the } \\
\text { transformation of Rashkiv into a town }\end{array}$ & $\begin{array}{l}\text { Private (Aleksander } \\
\text { Lubomirski) }\end{array}$ \\
\hline 1796 & $\begin{array}{l}\text { Purchase of Rashkiv by Catherine II for the } \\
\text { state treasury }\end{array}$ & State (Russian Empire) \\
\hline 1801 & $\begin{array}{c}\text { Transfer of Rashkiv to Volhynian governor } \\
\text { Tutolmin. Demolition of the Assumption } \\
\text { and Ascension churches, resettlement of } \\
\text { the Armenians }\end{array}$ & Private (Alexey Tutolmin) \\
\hline 1860 & Sale of Rashkiv to Barchevsky & $\begin{array}{l}\text { Private (Sobeslav } \\
\text { Barchevsky) }\end{array}$ \\
\hline 1913 & Construction of a zemstvo school & Private (Pavel Yurevich) \\
\hline 1924 & $\begin{array}{l}\text { Creation of the Moldavian ASSR within } \\
\text { Ukraine }\end{array}$ & \multirow{5}{*}{ Property right canceled } \\
\hline 1929 & $\begin{array}{l}\text { Creation of the collective farm "Truzhenik", } \\
\text { forced collectivization, repressions }\end{array}$ & \\
\hline 1940 & $\begin{array}{c}\text { Cancellation of the Moldavian ASSR, } \\
\text { inclusion of the region to the Moldavian } \\
\text { SSR }\end{array}$ & \\
\hline 1967 & Construction of a community center & \\
\hline 1990s & $\begin{array}{l}\text { The restoration and opening of the } \\
\text { Orthodox Holy Trinity Church and the } \\
\text { Roman Catholic Church of Saint Cajetan }\end{array}$ & \\
\hline
\end{tabular}

\section{Localization of the Kalaur castle of the $15^{\text {th }}$ century and of the Rashkiv settlements}

It is believed that the Castle of Kalaur on the Dnister was founded by the Grand Duke of Lithuania Vytautas to protect the southern borders of his state. The castle was first discovered and generally described by Aleksander Jabłonowski at the end of the 19th century. [1; 20:11]. According to his information, in 1888, V. Antonovych was there with his scientific expedition and described in details the remnants of fortifications in his article. [1]. Then he was found and published a document - an extract from the Vinnytsia city books dated 1580, which confirmed the hereditary connection of the fortress Kalaur (Karaul) and the Rashkiv settlement, which arose as a trading quarter outside of the fortress. The location of the castle in this area was caused by the following factors: the presence of a ford across the Dnister and, accordingly, of a crossing, and of a rocky inaccessible cape ${ }^{1}$, from which a perfect view of the Dnister valley opens. Exactly on the corner of this cape the fortress was built. Its earthen fortifications included a rampart and a ditch which formed a half-circle on the side of the fields; on 
the corners of the rectangle of the fortress were roundels, massive round bastion towers. The castle, as evident from its name ${ }^{2}$, performed a purely observational function and was not built for a long-lasting siege or assault.

Interestingly, in 1442, when Podilia was occupied by the Poles, Kalaur, together with Khadjibey (Odesa) and the Black City, were given for lifelong ownership to Teodoryk Buczacki Jazłowiecki with an order to restore fortifications [21, 22:25]. The questions about the measures taken here by Teodoryk still remain unclear. Perhaps he carried out only minor modernization works in the castle. Some scientists believe that he did not start any serious construction works, since in 1469 in the act of division of the Buczacki estates, Karavul was mentioned only as a village without any fortifications [23: 330]. In 1564, Karavul together with the mentioned settlement appears in the list of hereditary lands of the Jazłowieckis [24: 363], although in fact it was then owned since at least 1545 by the Chechels-Sidimuntovichs [25:] who then sold it to Jan Zamoyski.

The remnants of the fortress are recorded in the pace method survey of $\mathrm{S}$. Kovalenko of 2006. The width of the earthen rampart is $10-12 \mathrm{~m}$, the height is up to $5 \mathrm{~m}$. The state of the settlement is unsatisfactory, it is located under the woods, the top of the rampart is destroyed by later digging and holes of animals, the edges are wavy, the rampart has slid a lot. The ditch is almost not preserved. In the north-eastern section, there is a passage that levels down the rampart along its full vertical extent. After removing trees and shrubs, the settlement can be studied as a fixed site [26:18].

Regarding the location of the settlement itself, it is not possible to establish it precisely. We only assume that it was located in the area of the central part of the present Rashkiv. This version has indirect confirmation: on the banks of the river, near the crossing, along trade routes, in the valley of the Dnister and the Rashkiv River, this location was most convenient for location of the settlement, and the lengthy market square, which was still there in the 19th century, was typical for settlements of the 15th-16th centuries, which inherited the principles of the Rus' law (Fig. 2).

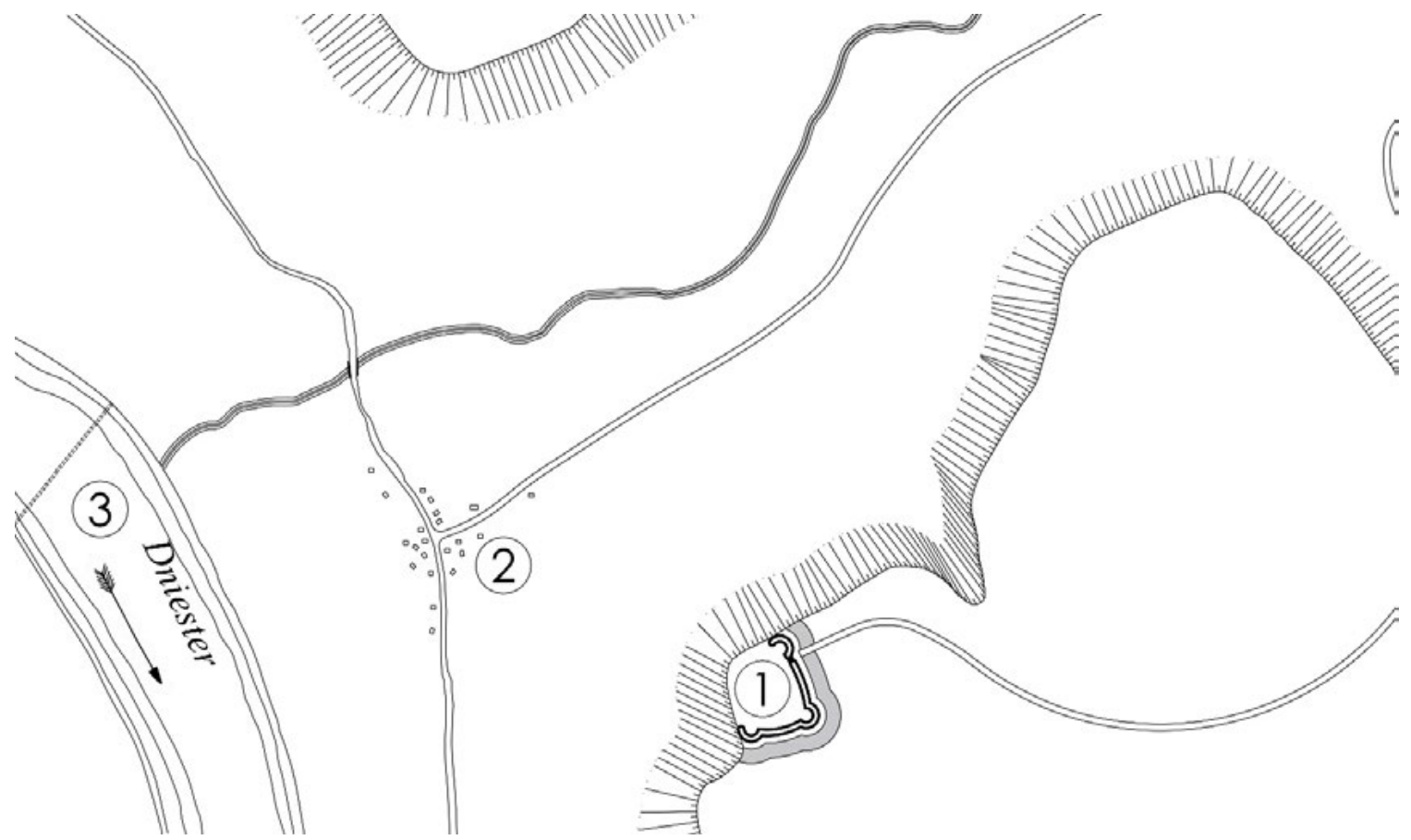

Fig. 2. Hypothetical reconstruction of the town-planning period of Rashkiv at the beginning of the 15 th century 1 . Fortress-Castle Karaul (Kalaur, Karawol). 2. Settlement of Rashkiv. 3. Crossing of the Dnister 


\section{Localization of urban fortifications and the castle of the Zamoyskis at the end of the $16^{\text {th }}-1^{\text {st }}$ half of the $17^{\text {th }}$ century}

After purchase by Chancellor of Poland Jan Zamoyski of the territories in Lower Dnister Region, he immediately addressed the issues of defense and colonization of these lands. For the defensive castle he chose the area at the mouth of the Rashkiv River. [27]. The castle was wooden; in 1600 it was destroyed and captured by the people of Kyiv voivode Prince Konstanty Ostrogski as a result of the conflict between Jan Zamoyski and Princes Ostrogski [28: 89-90]. The map of the Podolian Voivodeship by Beauplan shows us Rashkiv as a town fortified with two unclosed half-circles of defensive lines, and the Dutch geographer Andreas Cellarius described Rashkiv as a "mighty fortress on the border of the desert steppe" [29: 368]. Such powerful fortifications appeared, apparently, under the rule of the son of Jan Zamoyski - Tomasz - who had the Venetian architect Andrea dell'Aqua at his court. This military architect fortified Brody, perfected the fortress of Zamość, designed the castle in Zbarazh and the palace in Pidhirtsi and built a tower at the Cracovian Gate in Lviv. He sent the project of fortifications of Rashkiv to Tomasz Zamoyski in 1625. [30: 29-31].

The hypothetical planning scheme of the town and fortifications of this period was elaborated on the basis of remnants of the earth bastions, and some planning landmarks - market space, historical roads and configuration of the terrain - found on the site. (Fig. 3) The most difficult question is the location of the Zamoyski's castle. Since the map of Beauplan does not depict it. Taking into account the protests of Zamoisky's constables in 1600 about the founding of the castle at the mouth of the Rashkiv River and analyzing the relief, as the probable location of the castle the site on the corner of a flat hill was chosen. In favor of this hypothesis speaks also the fact of location of the administration of the lords, or of the court in the likely castle area before 1917, which may indicate the continuity of the separation of urban and castle (landlord's) territories. At this stage, the most plausible option is the conjugate combination of city and castle fortifications, as was the case in Bar, Chyhyryn, Medzhybizh and Zhvanets.

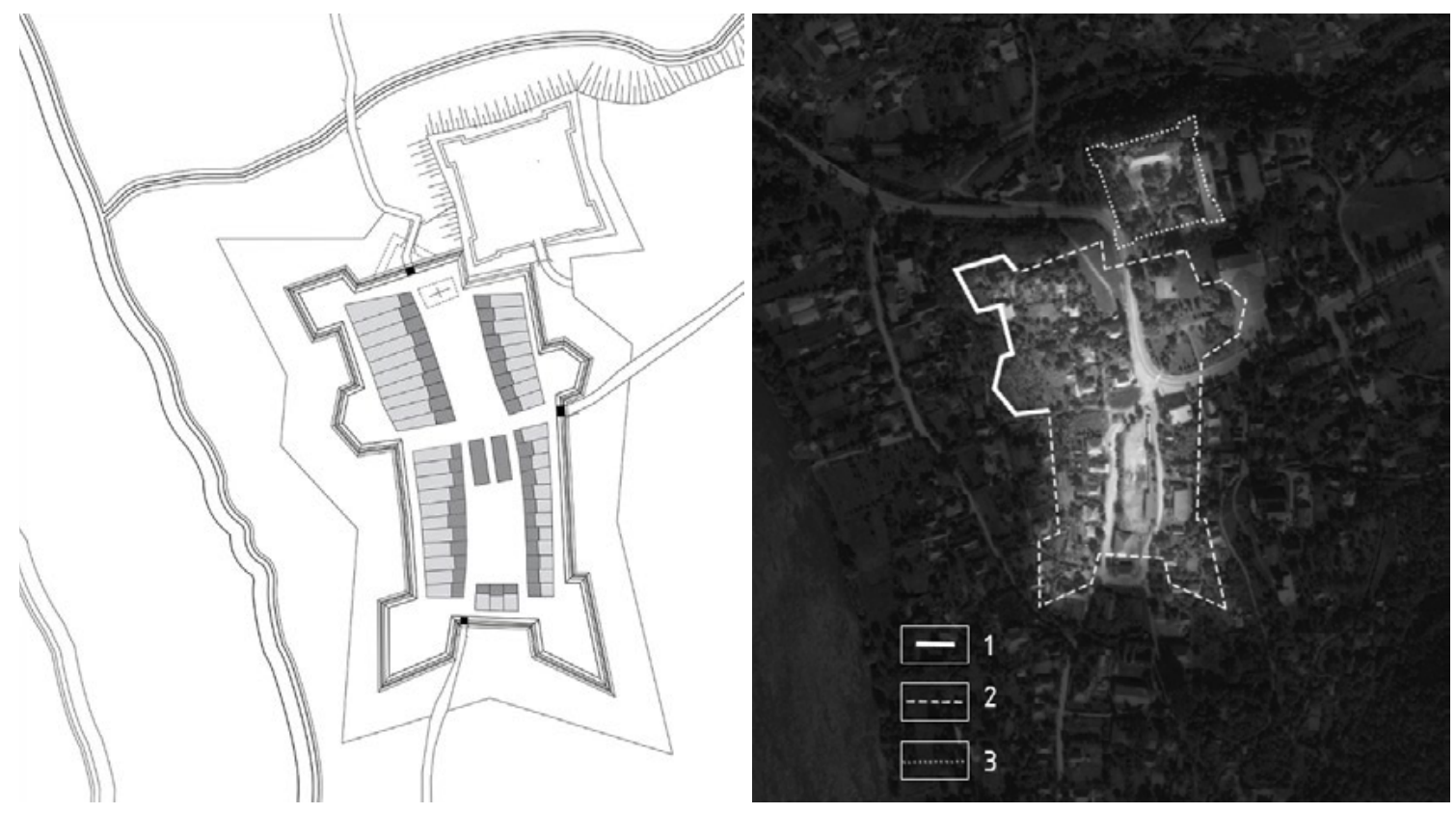

Fig. 3. Hypothetical reconstruction of the planning of the city center of Rashkiv, beg. of 17th century (left). Applying a traverse sketch of fortifications of the 17th century. on the modern orthophotomap (right): 1 - Remaining fragments of ramparts of the city center. 2 - hypothetical reproduction. 3 - probable location of the wooden residence castle 


\section{Localization of fortifications of the suburbs}

The growth of the population led to construction of housing in the suburbs which also needed to be defended. We have much more information about Rashkiv in the middle of the 17th century. First, there are recorded memoirs of travelers Evliya Çelebi and Patriarch of Antioch Macarios, who mention the fortress of Rashkiv, and Patriarch Makarios added about a wooden castle with guns. Cellarius calls Rashkiv a "mighty fortress on the border with desert steppe". Given that in 1671 there was a garrison of 7 cavalry choragiews of the Polish army [31: 584] (700-1000 people) in Rashkiv, we can assert that Rashkiv was a rather significant military argument of Poland in its southern borderland. On the map of Beauplan, Rashkiv is depicted as being fortified with two semi-circles of fortifications. This suggests that the project by Andrea dell'Aqua was implemented, and the expansion of Rashkiv (in 1654 there were 7 churches, thousands of inhabitants and a monastery in the town) led to the need to fortify the suburbs. Unfortunately, the only source maps for these fortifications are the maps of Beauplan, Friedrich Wilhelm Bauer and Rizzi Zannoni. Based on them, analyzing the present planning structure of Rashkiv, we can conclude that the outer perimeter of defense was not closed and adjoined the Dnister with its western end, and the Rashkiv River with its north-eastern end. The hypothetical outline of fortification of the suburbs is based on the study of relics of urban planning and some landmarks, in particular, the Jewish cemetery, the first gravestone of which dates back to 1709 when these fortifications still existed. Obvious is also that there was a bastion belt corresponding to its time and fixed on the mentioned maps. Thus, from the north, the settlement was covered with natural protection - the Rashkiv River - and the castle fortifications, which, as noted above, were connected with the city fortifications (Fig. 4).

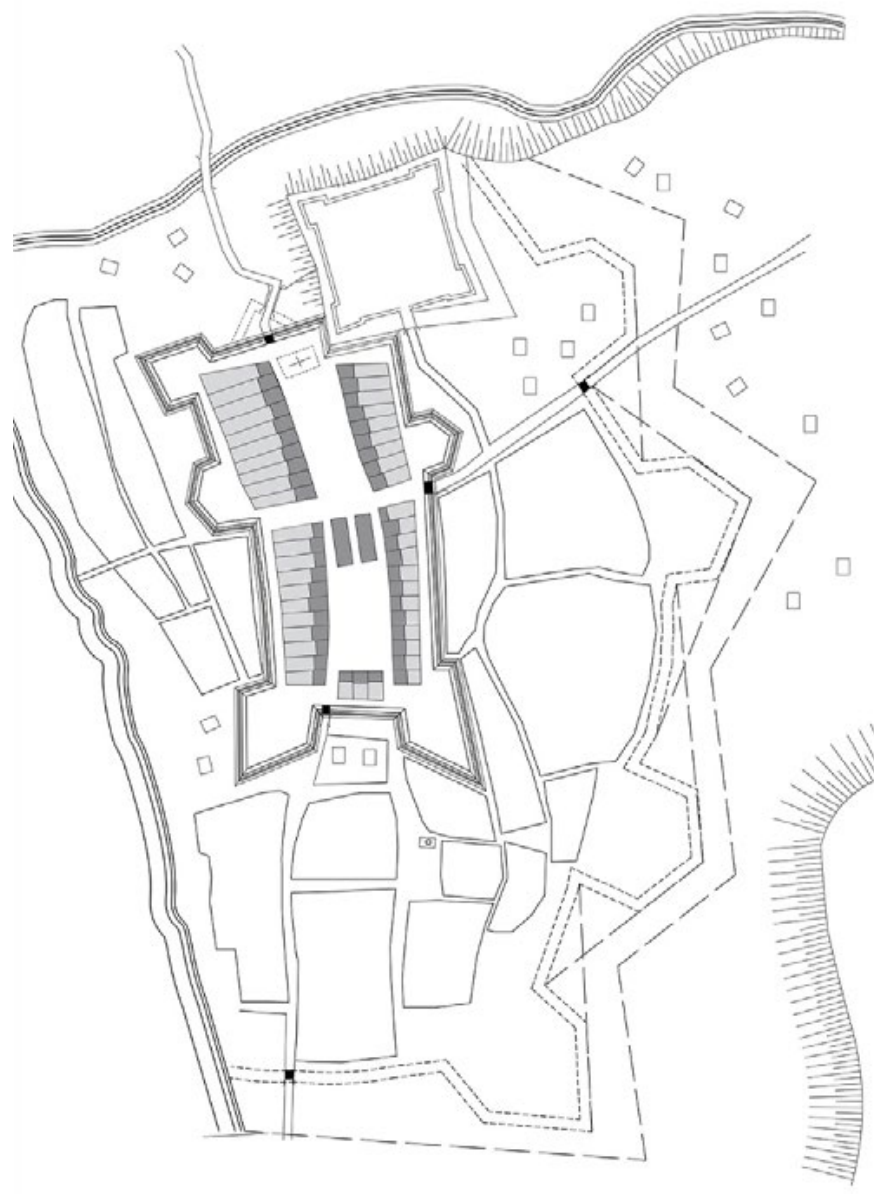

Fig. 4. Hypothetical reconstruction of Rashkiv's planning with fortified center and suburbs in the middle of the $17^{\text {th }}$ century. 
Table 2. Analysis of historical mapping of the $17^{\text {th }}-18^{\text {th }}$ centuries.

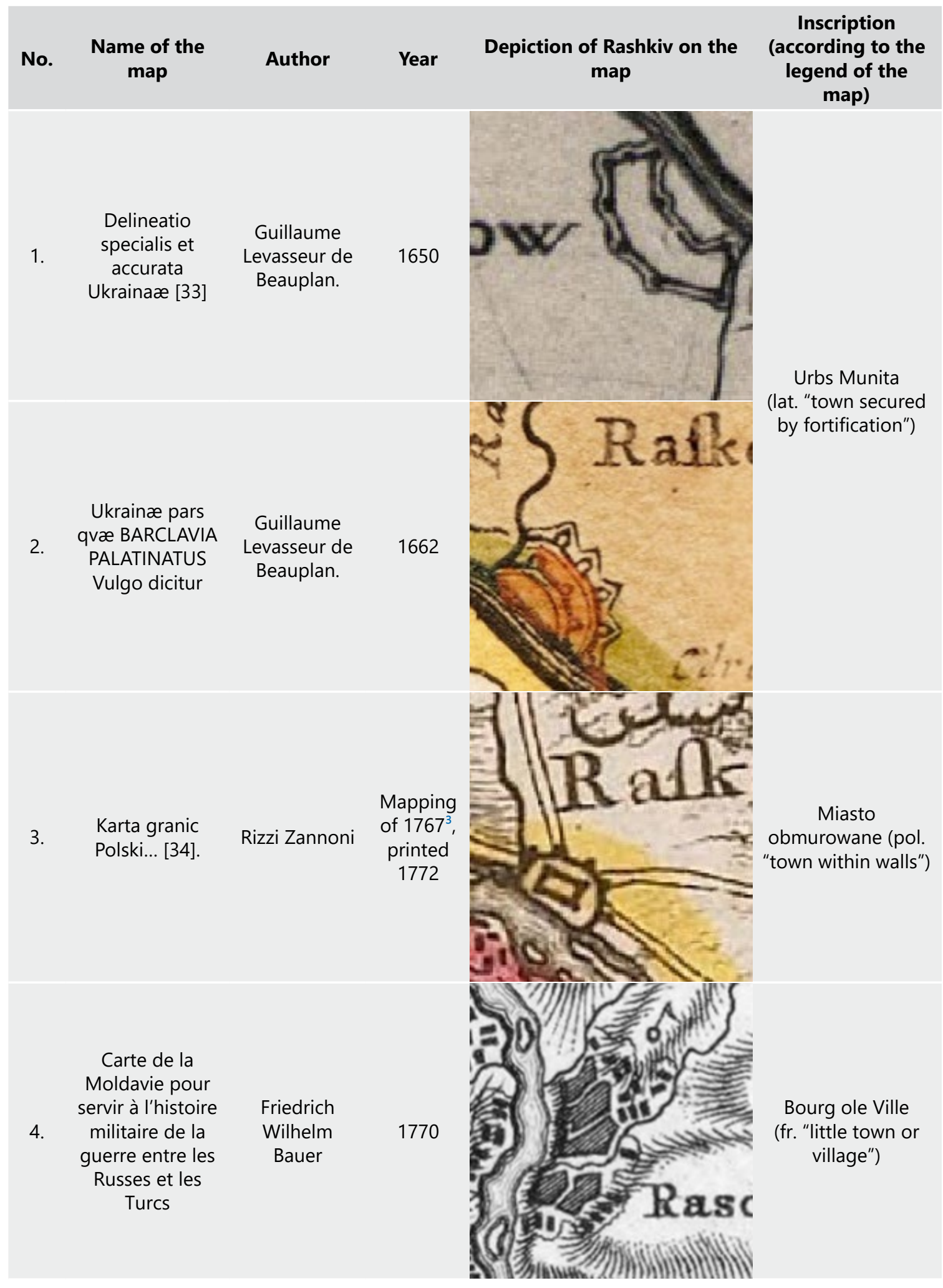


The description of the castle of 1662 was found in the inventory [32: 300], signed by the owner of Rashkiv Stanisław Koniecpolski, the voivode (governor) of Sandomierz, and Ruxandra Doamna Khmelnytsky, who received it in hypothecary ownership. According to the description, the castle was wooden-earthen, with bastions and "turrets" on the corners. The gate and the bridge led to the town. Inside, there were 2 buildings, gunpowder and sulfur warehouses, bath, a larder, stables, and a treasury above the gate tower.

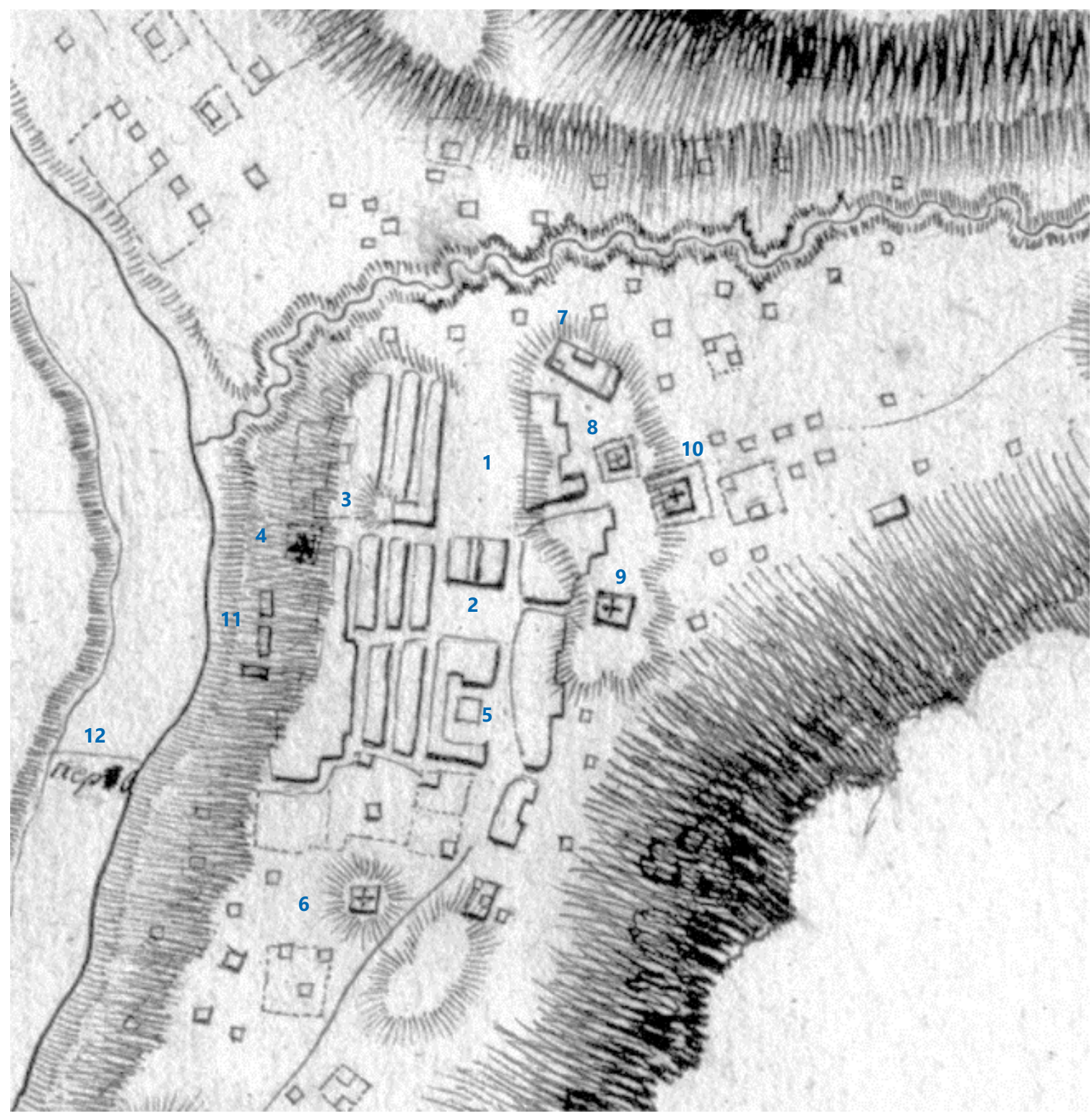

Fig. 5. Fragment of the plan of Rashkiv dated 1810 [39]: 1. Market square 2. Shops 3. Preserved earth bastion of town fortifications. 4. Dormition of Our Most Holy Lady Church 5. The Great Synagogue Complex. 6. Church of Our Lady's Mantle 7. Landowner's court 8. Ascension Church 9. Roman catholic church of St. Cajetan. 10. Trinity church. 11. Larders and storehouses. 12. River Crossing.

The "Plan of location at the town of Rashkiv", compiled by Lieutenant-General Simeon Alexandrovich Mukhin in 1810 helped to understand this issue (Fig. 5). The plan is an ocular estimation, sketched in black inked. Clearly obvious is the dense, formed in the $17^{\text {th }}-18^{\text {th }}$ centuries building system of the center, consisting of quarters and located within the limits of the outer defense perimeter, outlined by us in the previous section. Interesting is the urban composition of the market square, the southern part of which is flanked by a passage 
of stores. The Roman Catholic church of St. Cajetan, erected on an artificial hill above the center of the town, is located along the central broadwise axis of the southern half of the square. Although it is obvious that the plan is not accurate in proportions, there is a conditionality and simplification of the planning structure, which is very important information for this period of Rashkiv.

To test the hypothesis of preservation in modern Rashkiv of the end of the 18th century planning, an attempt was made to create a projection with the methods of descriptive geometry of the building from the historic photo-panorama of 1903 [28: 89-90] onto a modern orthophotomap and to count the number of streets (Fig. 6).

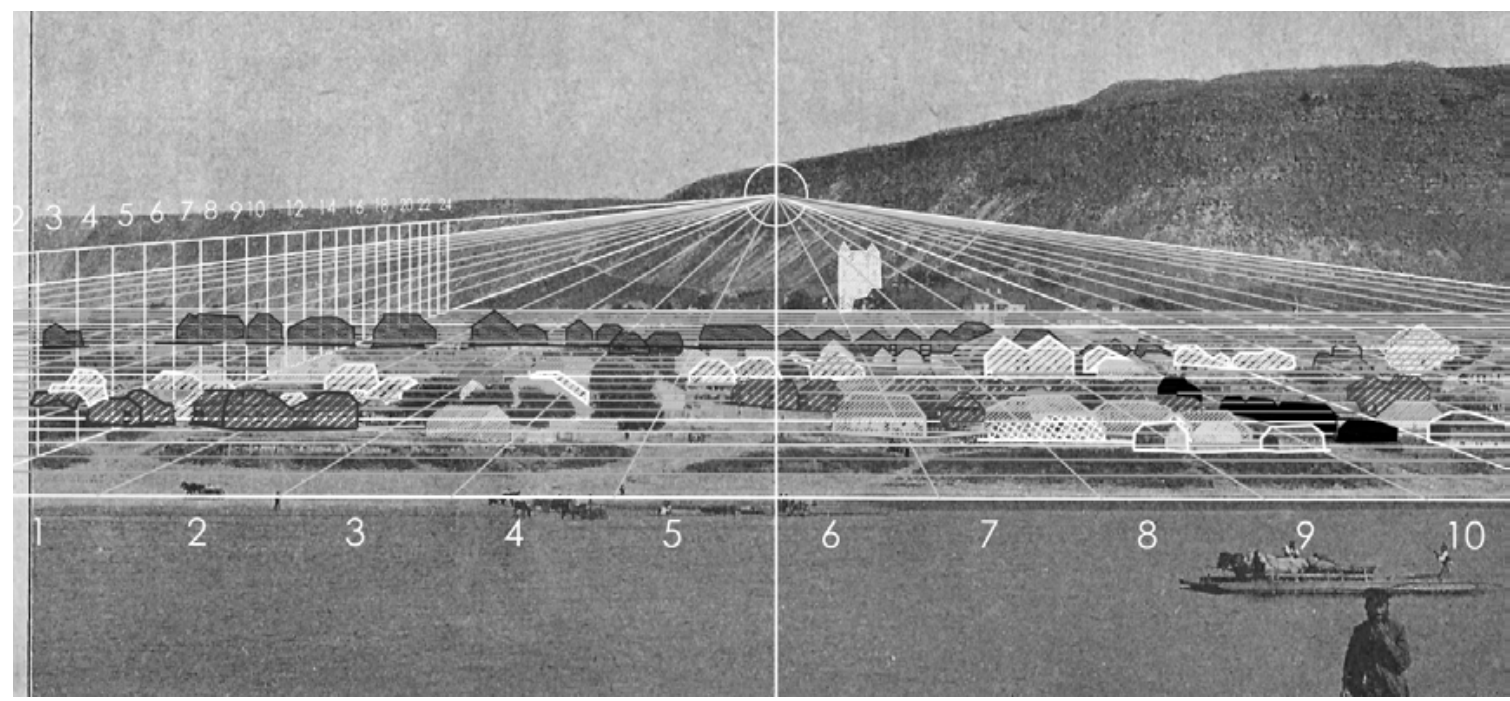

Fig. 6a. Identification of the street network and the buildings of the historical center of Rashkiv by the methods of descriptive geometry

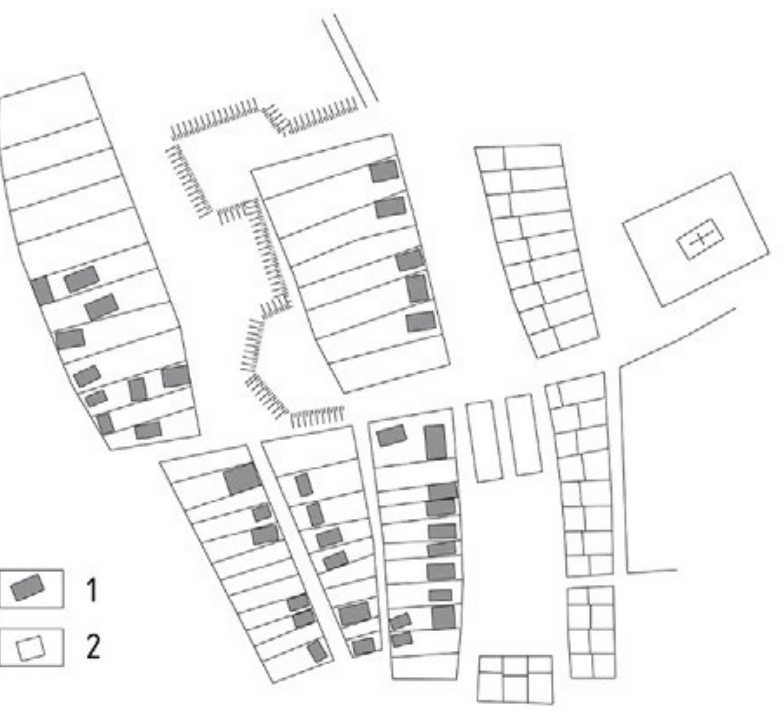

c)

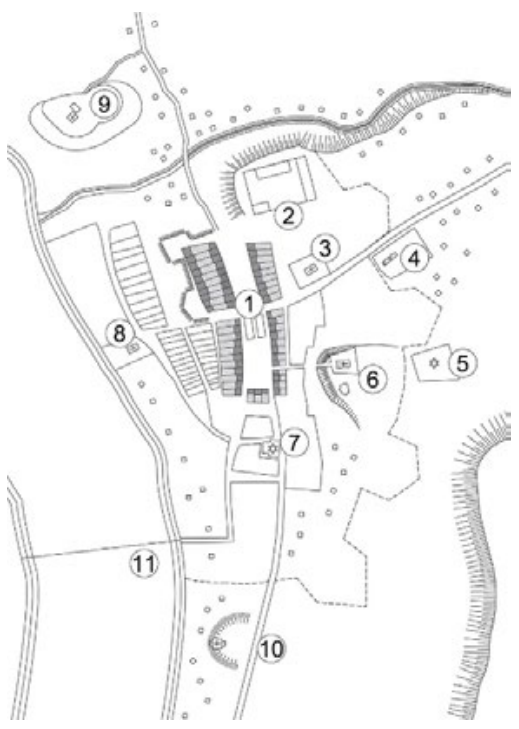

Fig. 6b. Projection of buildings from a historical photo (a sketch from the modern underlay): 1. Buildings seen on a photo-panorama of 1903. 2. Implicit reconstruction of quarters and parcels

Fig. 6c. Hypothetical reconstruction of the planning of Rashkiv in the 2 nd half of the $18^{\text {th }}$ century. 1. Market area with stores (partially preserved) 2. Territory of the defensive court or castle (not preserved). 3. Dormition of our Most Holy Lady Church, 1777 [41: 7-90] (not preserved), 4. Trinity church 1779 [42: 840-843] (preserved). 5. Jewish cemetery 1709 6. Roman catholic church of St. Cajetan, 1786 (preserved). 7. Synagogue of the 18th century (partly preserved) 8. Christ Ascension Church, 1700 (not preserved) 9. Church of St. Nicholas the Wonderworker (former monastery) (not preserved) 10. Church of Our Lady's Mantle 1780s (now in ruins). 11. Crossing of the Dnister. 


\section{Conclusions}

On the basis of the analysis of historical cartographic materials, published archival sources and rethinking the research of predecessors, it was possible to prove the location of Rashkiv at the foot of the ancient Lithuanian fortress Karavul at the beginning of the $15^{\text {th }}$ century. Field surveys and a careful study of cartographic materials allowed to spot the relics of the historical planning structure of the former town center and the suburbs of Rashkiv in the modern urban development situation. It was also possible to hypothetically outline the lost lines of fortifications, which surrounded the town center in the first stage, and included the suburbs in the second. The genesis of the town and the stages of the historical urban planning of Rashkiv in the period between the 15 th and the early $18^{\text {th }}$ centuries was reconstructed. In addition to fortifications, other elements of the old town were localized, in particular, the lost sacral objects.

The given hypotheses of the main periods of urban development provide the basis for further research, and the localization of lost defense and sacral buildings and structures is important for carrying out archaeological research. The materials of our research allow to supplement the lists of architectural, urban planning and archeological heritage. A further in-depth study of Rashkiv is needed to identify the remnants and detailed localization of lost fortification structures, civilian and sacral buildings, namely, the monastery complex of St. Nicholas, the castle of Zamoyski, fortification ramparts with bastions, curtain walls and gates. We believe that supplementation of the list of the archaeological cultural heritage by finding foundations of churches, monasteries, stone cellars of market square buildings of the $16^{\text {th }}-18^{\text {th }}$ centuries is promising. We plan to develop projects for their excavation, conservation and museumification, including the restoration marking of the lost buildings by landscaping and urban-designer means.

\section{List of references}

[1] Antonovich" V. Nbskol'ko dannykh" o zemlevladtníi v" yuzhnoy Ukraint v" XV stolttíi // Kíevskaya starina. 1896. № 10. S. $1-19$.

[2] Molchanovskíy I. Ocherk" izvtstíy o Podol'skoy zemlt do 1434 goda. Kítv", 1885.

[3] Tvory : u 50 t. / M. S. Hrushevs'kyy; redkol.: P. Sokhan' (holov. red.), I. Hyrych ta in. L'viv : Vydavnytstvo "Svit", 2002 T.16. / NAN Ukrayiny. Instytut ukrayins'koyi arkheohrafiyi ta dzhereloznavstva imeni M. S. Hrushevs'koho; Hrushevs'kyy M. S.. - L'viv: Vydavnytstvo "Svit", 2012. - XKHII, 250 s. : il. - 5000 pr.. - (Seriya "Retsenziya ta ohlyady" : 1905-1913).

[4] Słownik geograficzny Królestwa Polskiego i innych krajów słowiańskich. - T. 9: [Pożajście - Ruksze]/Red.: Chlebowski Bronisław, Sulimierski Filip, Walewski Władysław. - Warszawa, 1888. - $960 \mathrm{~s}$.

[5] Svod pamyatnikov istorii i kul'tury Moldavskoy SSR. Severnaya zona. Maket/Red.: Demchenko N. Kishinov: Shtiintsa, 1987.

[6] Arkhiv moldavs'koho derzhavnoho proektnoho instytut Moldhyprohrazhdansel'stroy (teper - UrbanProekt) №1210. Inv. № 155-68-110. Kyshyniv.

[7] Kravtsov S. Printsipy regulyarnogo gradostroitel'stva Halychiny XIV-XVII vekov. Dissertatsiya na soiskaniye uchenoy stepeni kandidata arkhitektury. Vsesoyuznyy nauchno-issledovatel'skiy institut teorii arkhitektury i gradostroitel'stva. Moskva, 1993.

[8] Bevz M. Metodolohichni osnovy zberezhennya ta reheneratsiyi zapovidnykh arkhitekturnykh kompleksiv istorychnykh mist (na prykladi Zakhidnoyi Ukrayiny). Avtoreferat dysertatsiyi na zdobuttya naukovoho stupenya doktora arkhitektury. Kharkivs'kyy derzhavnyy tekhnichnyy universytet budivnytstva ta arkhitektury. Kharkiv, 2004.

[9] Bevz M. Istorychni mista Halychyny: problemy vyvchennya i zberezhennya//Zapysky Naukovoho Tovarystva imeni Shechenka. Pratsi Komisiyi arkhitektury ta mistobuduvannya. L'viv: NTSH, 2001. T. CCXLI. C. 84-112.

[10] Rybchyns'kyy O. Formuvannya i revitalizatsiya seredmist' istorychnykh mist Ukrayiny. Dysertatsiya na zdobuttya naukovoho stupenya doktora arkhitektury. Natsional'nyy universytet «L'vivs'ka politekhnika». L'viv, 2017.

[11] Rybchyns'kyy O. Rynkovi ploshchi istorychnykh mist Ukrayiny. L'viv: Vydavnytstvo Staroho Leva, 2016.776 s.

[12] Długossii I. Historiae polonicae libri XII. 1711. 1168 c.

[13] Prochaska A. Codex epistolaris Vitoldi Magni Ducis Lithuaniae 1376-1430. Cracoviæ, 1882. $116 \mathrm{s.}$

[14] Daniłowicz I. Skarbiec diplomatów papiezkich, cesarskich, krolewskich, książęcych, posługujączych do krytycznego wyjaśnienia dziejów Litwy, Rusi Litewskiej i ościennych im krajów. T.1. Wilno, 1862.

[15] Polekhov. S. Spisok gorodov Svidrigayla. Datirovka i publikatsiya //Drevnyaya Rus'. Voprosy mediyevistiki. 2014. №4. S. $111-125$. 
[16] Nomina civitatum, castrorum et districtuum, quos possidet Swidrigall. Geheimes Staatsarchiv Preußischer Kulturbesitz (Berlin). Оригінал. XX. Hauptabteilung (Königsberger Archiv). Ordensbriefarchiv 27885. [арк. 1 об.]

[17] Żurkowski S. Żywot Tomasza Zamojskiego kanclerza W. Kor. Lwów, 1860, стор. 150-151

[18] Akty, otnosyashchiyesya k istorii Yuzhnoy i Zapadnoy Rossii, sobrannyye i izdannyye Arkheograficheskoy komissiyey: [V 15-ti t.]. T. 12 : 1675-1676. SPb., 1882. S. 136.

[19] Ibid, s. 106-107.

[20] Jabłonowski A. Atlas historyczny Rzeczypospolitej Polskiej. Epoka przełomu z wieku XVI-go na XVII-sty. - Dział II-gi: "Ziemie ruskie" Rzeczypospolitej. Warszawa-Wiedeń, 1899-1904.

[21] AGAD f. Tzw metrika litewska. Sygn. 10.6. Sygn. 17. "Kopie dokumentow rewizji województw podolskiego i bełskiego z 1564 roky".

[22] Hrushevskiy M. Barskoye starostvo, istoricheskiye ocherki (XV-XVIII v.). Kiïv, 1894.

[23] Akta grodzkie i ziemskie z czasów Rzeczypospolitej Polskiej z archiwum tak zwanego bernardyńskiego we Lwowie w skutek Fundacyi śp. Aleksandra hr. Stadnickiego. T.12. Lwów, 1887.

[24] Arkhiv Yugo-zapadnoy Rossii, izdavayemyy vremennoy komissiyey dlya razbora drevnikh aktov, vysochayshe uchrezhdennuyu pri Kiyevskom Voyennom, Podol'skom i Volynskom general-gubernatore: [V 37 t.]. Chast. 8, tom 2. Materialy dlya istorii mestnogo upravleniya v svyazi s istoriyey soslovnoy organizatsii. Akty Barskogo starostva XVII - XVIII v. Kiyev, 1894.

[25] Lytovs'ka metryka. Knyha 561: Reviziyi ukrayins'kykh zamkiv 1545 roku / Pidhotuvav V. Kravchenko; Nauk. tov. im. Shevchenka v Amerytsi, Nauk. tov. im. Shevchenka v Ukrayini, NAN Ukrayiny, Instytut ukr. arkheohrafiyi ta dzhereloznavstva im. M. S. Hrushevs'koho. Kyyiv, 2005. 597 s.

[26] S. I. Kovalenko, V. S. Sinika, Ye. F. Tashchi, N. P. Tel'nov, S. A. Fidel'skiy, I. A. Chetverikov, T. A. Shcherbakova. Svod arkheologicheskikh pamyatnikov Kamenskogo rayona Pridnestrovskoy Moldavskoy Respubliki. Tiraspol', 2006.100 s.

[27] AGAD f. 358. № 2876. S. 43.

[28] Kempa T. Konflikt między kanclerzem Janem Zamoyskim a książętami Ostrogskimi i jego wpływ na sytuację wewnętrzną i zewnętrzną Rzeczypospolitej w końcu XVI wieku//Альманах соціальної історії. 2010. №9. 404 c.

[29] Cellarius A. Regni Poloniæ, magnique ducatus Lituaniæ omniumqæ regionum juri polonico subjectorum novissima descriptio. Amsterdam, 1659. 712 p.

[30] Herbst St. Twierdza Zamosć, Warszawa, 1936. s. 413.

[31] Akty... T. 9 : 1668-1672. - SPb., 1877, c. 584

[32] Białkowski L. Kilka dokumentów do dziejów Rusi południowej w wieku XVII i XVIII // Pamiętnik Lubelski, t. 3: Za lata 1935-1937. Lublin, 1938.

[33] Beauplan W. Delineatio specialis et accurata Ukrainaæ арк. 1-3 Kamieniec Podolski // Jagiellońska Biblioteka Cyfrowa bc id: 266602, 1650.

[34] Zanoni R. Karta granic Polski, zacząwszy od końca gór Karpackich w Siedmiogrodzie, aż do osady Tatarów Bessarabskich, Zawieraiąca Moldawią Pułnocną, stepy Tatarów Lipków, y wyciągnienie Dniestru od Chocima aż do Benderu University College of London, School of Slavonic and East European Studies, 1772.

[35] Sapozhnikov I. Livoberezhne Podnistrov"ya v seredyni XVIII stolittya (za danymy kartohrafiyi). Mashynopys avtora, 2000.

[36] URL: http://chtyvo.org.ua/authors/Sapozhnykov_Ihor/Livoberezhne_Podnistrovia_seredyni_XVIII_stolittia_za_danymy_ kartohrafii (дата звернення: 29.10.2018)

[37] Rusov A. Russkiye trakty v kontse XVII i nachale XVIII vekov i nekotoryye dannyye o Dnepre iz atlasa kontsa proshlogo stoletiya. Kiyev, 1876. 47-150 s., 1 I. k.

[38] Skochylyas I. Pivdenna mezha Halyts'koyi (L'vivs'koyi) yeparkhiyi u XV - XVIII stolittyakh (Istoryko-heohrafichnyy aspekt)// Ukrayins'kyy arkheohrafichnyy shchorichnyk, Vyp. 13/14. (red. Sokhan' P.). NAN Ukrayiny. Arkheohrafichna komisiya, Instytut ukrayins'koyi arkheohrafiyi. Kyyiv, 2009, s. 318.

[39] RGVIA F. 846. Op. 16. Spr. 19764. Ark. 5-1, 5-2.

[40] Bessarabiya. Graficheskiy, istoricheskiy, statisticheskiy, ekonomicheskiy, etnograficheskiy, literaturnyy i spravochnyy sbornik / pod red. P.A. Krushevan. Moskva: Izd. gazety «Bessarabets», 1903. 528 s.

[41] Trudy Komiteta dlya istoriko-statisticheskogo opisaniya Podol'skoy yeparkhii, vyp. 2. / pod red. Setsinskiy Ye.. Kamenets-Podol'skiy, 1879.

[42] Trudy Podol'skogo yeparkhial'nogo istoriko-statisticheskogo komiteta: Prikhody i tserkvi Podol'skoy yeparkhii, vip. 9. / pod red. Senitsskiy Ye. Kamenets-Podol'skiy, 1901.

[43] Proyekt planirovki i zastroyki okhrannoy zony istoriko-landshaftnogo kompleksa sela Rashkova Kamenskogo rayona. Ob"yekt № 10614, Moldavskiy gosudarstvennyy proyektnyy institut «Moldgiprograzhdansel'stroy», Gosstroy SSSR, 1975. 